IJ§ER

ISSN: 2149-5939
International Journal of Social Sciences and Education Research

Online, https://dergipark.org.tr/tr/pub/ijsser

Volume: 7(2), 2021

\title{
Attitude of Afghan youths on watching foreign dubbed serials: A case study of Takhar University, Afghanistan
}

\author{
Besmillah Daqiq ${ }^{\text {a* }}$ and Aminuddin Hashemi ${ }^{\mathrm{b}}$ \\ *Corresponding author \\ ${ }^{a}$ Takhar University, Taloqn, Takhar Province, Afghanistan.besmillahraqiq@gmail.com ORCID: https://orcid.org/0000-0003-0548-393X \\ ${ }^{b}$ Takhar University, Taloqn, Takhar Province, Afghanistan.a.hashemi@tu.edu.af, ORCID: https://orcid.org/0000-0002-6052-1516
}

\begin{tabular}{ll}
\hline Article Info & Abstract \\
\hline Research Article & $\begin{array}{l}\text { The leading intention of this study was to discover the attitude of Afghan youths on watching } \\
\text { foreign dubbed serials. The data were collected from } 80 \text { students including male and female }\end{array}$ \\
Received:3 February 2021 & who were studying at Takhar University in various majors. The participants were chosen \\
Revised: 14 April 2021 & randomly. The research instrument was a semi-structured interview. The data were analyzed \\
Accepted: 23 April 2021 & based on thematic analysis. The outcome of the research is indicative that $96 \%$ of youths \\
& watch foreign dubbed serials, but $90 \%$ of them think that watching foreign dubbed serials \\
Keywords: & have negative impacts on Muslim youths. Their reason is that the foreign dubbed serials like \\
Attitude, & Turkish, Indian, and Americans are full of matters such as kidnapping, divorce, living in \\
Afghan Youth, & pleasure, drinking wine, illegal love affairs, and family distrust that change the minds of \\
Dubbed serials, & youths and guide them to apply those matters in their daily lives which are against Islamic \\
Takhar University, & values. Also, the result of the study illustrated that $80 \%$ of the study participants believe that \\
Case Study & foreign dubbed serials are extremely broadcast in Afghanistan because Afghanistan is a \\
& colonial and dependent government. Therefore, it is forced to implement the commands and \\
purpose of superpower countries by any medium.
\end{tabular}

\section{Introduction}

Watching TV shows and serials are widely prevalent among Afghan youths due to various national private television network broadcasts. Broadcasting foreign dubbed serials in Afghanistan has changed the mindset of many Afghan youths who watch the serials in the last one and a half-decade. According to Luyken et al (as cited in Blinn, 2008), dubbing is that the original dialogues are recorded with spoken dialogues by native speakers keeping the original music and sound-effects track. Therefore, the series becomes simple and understandable for the audiences of importing countries. Ann Morris (1961), stated that there are two special fascinations of television to the two senses of hearing and seeing that makes it a strong type of communication. It is television that has provided rich and various experiences to people. The fastest exporter of television serials in the universe after the US in Turkey. Turkish dubbed shows are usually available in many languages. Turkish serials have become famous since 2000 (Aslam, Ali, Ullah, Munawar, \& Maria as cited in Naz, \& Iraqi, 2017).

Some countries like Russia, India, Turkey, South Korea, China, France, Japan, Germany, Britain, and the USA spend plenty of money on media as an instrument of public diplomacy in so that obtain soft power in particular scopes and across the Universe( Olson, as cited in Khan \& Rohn, 2020). The goal of Turkey for standardization is through cultural production and changing it into the industry as once America followed the same path for the production of standardized products. Turkey has spread widely its culture to the region and globe via media such as television, music, art, cinema, and soft power (Machin \& Leeuwen as cited in Khan \& Rohn, 2020). Buccianti (as cited in Alradimi \& Al-Ali, 2019) asserted that the stimulation of watching dubbed serials is due to the interest that watchers catch from imported contents.

\footnotetext{
* All responsibility belongs to the researchers. All parties were involved in the research of their own free will.
}

To cite this article: Daqiq, B. \& Hashemi, A. (2021). Attitude of Afghan youths on watching foreign dubbed serials: A case study of Takhar University, Afghanistan. International Journal of Social Sciences and Education Research, 7 (2), 173-180. DOI: https://doi.org/10.24289/ijsser.874101 


\subsection{Purpose statement}

Vast broadcast of foreign dubbed serials through domestic televisions networks in Afghanistan makes it crucial to study the attitude of Afghan youths on watching foreign dubbed serials at Takhar University

\subsection{Significance of the study}

This study will be conducted in Afghanistan where since 2001 the foreign dubbed serials broadcasting through domestic television networks is increasingly attracting more viewers. The outcomes of this research will be useful for youths to waken them to not waste their precious time watching misled dubbed foreign serials. On the other hand, it will help the scholars, teachers, chaplains, and knowledgeable individuals to preach the negative consequences of watching dubbed foreign serials on family lives. Besides, it will assist the ministry of information and culture to review its policy regarding broadcasts in a way that does not harm the Islamic values.

\subsection{Problem statement}

The broadcast and presence of foreign dubbed serials through domestic television networks of Afghanistan is very considerable and remarkable. The continuous and increasing rate of series exposure to viewers has impacted on whole viewers, particularly youths. Most families who have television, usually watch the broadcast programs. However, the television networks most of the time broadcast foreign dubbed series that are against Islamic values and culture and public will. As a result of broadcasting the series, the youths who are exposed are addicted to watching them on one hand. On the other hand, they are changed mentally, behaviourally, and apply the contents of the watched dubbed series in their daily lives which is leading them to a dark path. Hence, it is vital to study the attitude of Afghan youths on watching foreign dubbed series in Takhar, Afghanistan.

\subsection{Research question}

- This study seeks to answer the following questions:

- What are the reasons that Afghanistan youths watch foreign dubbed serials?

- What are the attitudes of Afghanistan youths on watching foreign dubbed serials?

- What are the consequences of watching foreign dubbed series on Afghan youths?

- What are the reasons that domestic television networks broadcast foreign dubbed serials extremely?

- Why does not the government prevent the broadcast of foreign dubbed serials in Afghanistan?

\section{Literature review}

\subsection{The contradiction of foreign dubbed serials with Islamic culture}

According to Hedayati, the clerk of Shia Scholar's council in the Injil district of Herat province (as cited in Sadai Afghan News Agency, 2016), western Turkish serials do not match with Afghanistan culture, and broadcasting them reveals the western countries vast cultural invasion in Afghanistan. Hedayati also added that broadcasting such films and serials in a traditional community that most of them are illiterate causes that people accept the stranger and non-Islamic culture and use them as models. He said that the existence of cultural, scientific, and fiscal poverty in Afghanistan society and broadcasting these kinds of serials have increased the rate of marriage age and divorce. He also cited that in our society, some women tended further to luxury-oriented with patterning the broadcasted films and serials. Therefore, if the husbands cannot provide the desire of their wives, their lives will be filled with full of difficulties and they move toward divorce. Moreover, he quoted the speech of some parents in Herat that said releasing such serials teach the illegal relationship of a married woman with a single man and vice versa that damage the families' bases.

According to Asifi (2012), Turkey is one of the Islamic and liberal countries in the Middle East and the producer of the most popular serials that have lots of viewers in the world. One of these serials is Gomish. It was the first Turkish serial in 2005 that created different reactions across the Arab world. This serial displays the life story of a girl who grows in poverty and then gets married to a rich man. In this serial, actors drink wine and accept performing sexual intercourse before marriage. The negative content of this serial has raised the anger of clergies and religious groups in the Arabic world. The religious anger was as much as that the Saudi Arabia chief of judge commanded collecting and stopping this serial and issued the death sentence of television networks' owners who broadcasted this serial. Besides that, the popular Turkish serials like Gomish, Slaiman 'Usmani Imperator' and Hazaro Yak Shab have a negative cultural effect and has a major role in the expansion of the Turkish economy. Most of the viewers of these serials consider Turkey as a country that has modern and welfare Muslims. 
People believe that raising of desires, luxury tendency, taking easy of illegal relations, and wine drinking among people are the consequences of watching and exemplifying foreign series such as Turkish and Indian. Husband and wife distrust in their lives causes divorce. Films, wrong social behaviors, and wrong phone contacts have caused husbands and wives distrust and can eliminate the legal relation of families. Decreasing of marriage statistics, increasing of derelict children, and moral corruption are some negative consequences of divorce that factor is watching the aforementioned serials (Jafari, a teacher in Alzahra Educational Center, as cited in Sadai Afghan News Agency, 2016). According to Mrs. Jafari, lots of husbands and wives get a divorce in Afghanistan, particularly in Herat province daily and they say that watching Turkish and Indian films and serials have increased their desires.

According to Fooladi (as cited in Sadai Afghan News Agency, 2017), the media activists in Herat believe that broadcasting Indian and Turkish films has opposition to Islamic culture and also contradicts to free of speech. They say that if broadcasting of these films continues, leads them to the wrong track. Mr. Fooladi added that besides cultural issues, the content of these serials represents the familial treachery and violence that also of opposition to Afghanistan peoples' culture, direct them to the wrong way. Escaping from prison, having illegal relations with aliens and other unlawful behaviors are the issues that these films and series have caused socially and inserted in the mind of the audience, especially youths and teenagers. He believes that the government can prohibit film broadcasting, but it does not take action. He stated that broadcasting these serials via domestic televisions is a kind of soft war and invasion of non-Islamic and western countries on Islamic countries. He also added that this cultural invasion is purposeful. The aim is to change the minds and thoughts of Muslim youths; otherwise, the media broadcasters and heads know better that such serials cost millions of dollars to be broadcasted. However, the question is here that why these dubbed serials are available and broadcasted for Afghanistan people without any cost and expenses? Why these serials are not free of charge in western countries?

Saljooqi 'one of the other media activists in Herat (as cited in Sadai Afghan News Agency, 2017), claimed that the matter of spreading Turkish and Indian serials in Afghanistan has a long-term purpose. He believes that the major purpose of Indian serials broadcasting is enhancing the Indian economy. However, one aspect of the Turkish serials' aim is that Afghanistan people follow the Turkish people as models and the ground becomes paved for Turkish future strategies' implementation. He also pointed to the negative impact of these serials in the Turkey community as well and said according to one investigation in Turkey, divorce has increased to forty percent in this country in the past four years. This statistic reveals the negative effect of these serials in Turkey itself too. According to Hashemi and Kew (2021), broadcasting such kinds of serials can cause cultural tension, the tension between two generations, increasing distrust among generations and family members and tribes. He also added that the only forces that can stop spreading these serials in Afghani society are religious scholars, elites, educators, and students by putting pressure on the government and media centers. In the end, he said that the artists and government should work on a domestic film production that represents the Afghani culture instead of broadcasting foreign misleading films.

According to Qazi Zadeh 'the head of Kahndazh News Site in Herat (as cited in Sadai Afghan News Agency, 2017), broadcasting these serials has put plenty of negative effects on youths' life such as wasting their times and leaving their education. He added that in these Turkish and Indian serials women and men have more action freedom. Therefore, this issue has encouraged the youths to watch them eagerly. He said that these serials are made and broadcasted against the Islamic culture and custom of Afghanistan. The infidels aim to inject and locate western democracy in the mind of the youth generation. He stated that the role of media is to prepare and broadcast educational and moral programs more to enhance the youths' generation level of knowledge and culture instead of these serials that are just seductive that spread revelry and anti-Islamic issues.

\subsection{The contradiction of foreign serials to Islamic morality}

According to Fars News (2014), Turkish serials have become one of the most important cultural goods export of that country and it has customers in many countries. For instance, one Turkish serial represents the life story of King Suleiman 'one of the most important Osmani kings, but it doesn't match completely with the political, social, and historical situations of king Suleiman period. Its main theme displays the quarrel and competition of court women and power and money dealers. For making the product more attractive, the producer of the serial has used European semi-naked clothes for women and French model velvet clothes for men instead of the usual clothes of the Osmani Imperial period. This is while the left paintings from king Suleiman period and also the old pictures of the last decades of this imperial life show that the nudity of women was not usual as it is revealed in the mentioned serial. 
The moral and social deviation rate and fear of the vast and profound negative effect of the serials are as much as that Belent French 'the deputies of the prime minister and the spokesman of state board' and also Husain Chelik 'spokesman of Justice and Development Party' called these products and works destructive and declared that continuation of this process will threat the morality and familial religious and sound relations of Turkey people seriously.

The research was conducted regarding the effect of foreign content in Pakistani society and on their cultural and religious values. A qualitative methodology was used to collect data. The data was gathered via a questionnaire filled by hundred respondents. The result revealed that people think that Turkish dramas are harmful to their Islamic society because people in Turkish drama drink alcohol, wear short dresses, have illegal activities, and the concept of female suppression. However, knowing the facts, people still want to watch more Turkish Dramas (Naz, \& Iraqi, 2017).

According to Anwari (as cited in BBC Persian News Agency,2008), the ministry of information and culture and the religious scholars' council opposed foreign serials broadcasting reasoning that the serials are against Islamic values and damage Islamic values. The stories of these serials are all about their own families' matters. The points which are opposite of Afghanistan people culture. For instance, the main hero of one of the Indian serials is a woman. She is forced to get married more than three times because of various reasons. Another example is that one woman is accused that a strange man has done sexual intercourse with her and has made her pregnant and this accusation separates her from her husband and family. Then she always thinks regarding how to live lonely with this baseborn child and finally, she tries to defend herself from her status. In the other scene, a father says to his illegal child "for love and living together only legal relation is not the condition", but human beings can have a relationship with having human and emotional relation. Showing such behaviours in Afghanistan traditional society is strange and unlawful that has stimulated the reactions of clergymen and ministry of information and culture authorities. Abdul Karim Khuram the 'former minister of information and culture of Afghanistan', as opposed to such serials and stated his opposition reasoning as below. "For example, one woman in one serials' story has four husbands at the same time, live with four men and has an illegal child; these are what our children see and are affected seriously". In some parts, the Indian serials' actors and actresses express their emotions about issues that are illegal in Afghanistan and even likely in India. In some scenes of these serials, a strange girl and boy talk about love. The religious council of Afghanistan says that these talks between strange girls and boys are seductive and destructive. According to Enayatullah Baligh member of the religious scholars' council and the Imam of Poli Kheshti Masjid( as cited in Anwari,2008), the reason of religious scholars about stopping the broadcasting of serials is that they are against Islamic morality and show naked females and stimulating deeds.

The research was done about dubbed series and their possible effects on Jordanian adolescents. The participants' were 1100 Jordanian adolescents. The data were collected through a questionnaire. The finding of the study exposed that $94.9 \%$ of males and $84.9 \%$ of females viewed dubbed series and liked to watch them (Qudah \& Tahat, 2013).

\subsection{The danger of foreign serials' broadcasting on youths' generation future}

According to Haqparast assistant professor of Shahid Rabani Education University (as cited in Sadai Afghan News Agency, 2012), the broadcasting of Turkish, American, and Indian serials by Afghanistan media is outcast based on Islam religion. He stated that most of the video media of Afghanistan engagement is broadcasting Turkish and western serials and it exposes that they are against Islam religion. He added that these serials are unlawful, lead the Islamic community toward moral corruption, prevents youths from reading Holy Quran, our prophet's tradition and morality, spread Jewish and Christian programs, and hazard the future of youths' generation. He said that the concessioners of these Afghani media are Afghan figures, but western countries encourage and support them to broadcast such misleading serials. He requested seriously from the ministry of information and culture to not let the media broadcast the aforementioned seductive serials.

On the other hand, Khan and Rohn (2020) conducted an online survey about the title of "the transnational role of television production in general and the specific case of the impact of Turkish television serials" in Pakistan and Egypt. Five hundred twenty-nine audience members from Pakistan and 423 audience members from Egypt filled out the survey. From Pakistan, survey participants were 58\%male and $42 \%$ female, while Egyptian respondents were $52 \%$ male and $48 \%$ female. A 5 point Likert scale questionnaire was used. The outcome of the study showed that most of the participants liked to watch television series that contain contemporary and historical 
issues. Many of the respondents believed that Turkish television series aims to motivate others to visit Turkey and/ or purchase Turkish products.

\subsection{Watching violent movies and their effects on youths}

According to Anderson et al (2003), the youths who watch violent scenes often have more aggressive emotions, thoughts, and behaviour than those who do not watch. An investigation was conducted on boys by putting them into two cottages. One group had violent movies to watch every night for five nights and the other group had nonviolent movies to watch. The study result revealed that the boys who watched violent movies had a physical attack on their cottage mates at a higher rate than those who watched nonviolent films (Berkowitz, as cited in Anderson et al, 2003). According to Stapleton (as cited in Morgan, 2002), the impact of virtual violence is longlasting. He believes that entertainment violence fills the mind that the universe is the place of violence. Also, he believes that viewing violence as an acceptable matter might expand a tendency for real-life violence, and children who watch TV violence have more trend for aggressive treatment in the future.

\section{Methods}

The design of this research is qualitative. This kind of research design was chosen because through it the researcher can dive profoundly into the mind of respondents and ask more open questions to collect more drastic and reliable data. Eight main open-ended queries were used to collect responses from participants.

\subsection{Sample}

The study respondents were composed of 80 university students both male and female equally from various majors who were studying at Takhar University. The research respondents were chosen randomly.

\subsection{Instrument}

According to Cassell and Nunkoosting (as cited in Alsaawi, 2014), the most common means of gathering data in a qualitative research interview. The research instrument was a semi-structured interview. The questions were adapted from "Effects of Turkish Dramas on University Students: A Survey of Pakistani Universities" developed by Iqbal (2018).

\subsection{Data collection procedure}

In the beginning, the interview questions were developed. Then they were translated into the Dari language. Next, the respondents were identified. After that, they were asked whether they are ready to take part in the interview process. After their agreement, the purpose of the interview was explained to the interviewees. Then the place, date, and time of interview were specified. For recording the interviewee's voices, the mobile phone was employed. Next, the interview was done at the exact time and the data were collected for analysis. Finally, the recorded data was transcribed for choosing the relevant points. Also it worth to be stated that some of the data in the literature review part were collected from various internet sites which were into Dari language and then translated into the English language.

\subsection{Data analysis}

Analyzing data is the process of checking and explaining the collected data by breaking it into main components to expose its structures, features, and themes. According to O'Connor and Gibson (2003), the data should be organized in a mode that is easy to look at, and that assist the researcher to study each point to pick out concepts and issues. In this study, for data analysis, thematic analysis was used to put the gathered data into particular relevant themes. First, the data were coded and categorized regarding each question one by one. Then the responses were set based on their relevant themes.

\section{Findings}

The researcher investigated the attitude of youths on watching foreign dubbed serials. The findings of the study revealed that $95,5 \%$ of the interviewees watch foreign dubbed serials, and $4,5 \%$ of the participants never watch foreign dubbed serials. The outcome of the investigation exposed that $54 \%$ of the respondents usually watch Turkish and Indian serials, $28 \%$ of the respondents watch only Turkish dubbed serials, $10 \%$ of the respondents watch Turkish, Indian, and American dubbed serials, $4 \%$ of the participants watch Turkish and American serials, and $4 \%$ of the participants never watch foreign dubbed serials. Also, the result of the research is indicative that 
$77 \%$ of the participants watch foreign dubbed serials 2 hours in 24 hours, $19 \%$ of the participants watch foreign dubbed serials 1 hour in 24 hours, and $4 \%$ of the respondents never watch foreign dubbed serials.

In addition, the study finding demonstrated that $81,1 \%$ of the respondents watch foreign dubbed serials for entertainment, $9,4 \%$ of the research subjects watch foreign dubbed serials to learn life affairs, $3,8 \%$ of respondents watch foreign dubbed serials to get information concerning foreign culture, $1,1 \%$ of the study subjects watch foreign dubbed serials due to their eagerness, and $4,4 \%$ of the participants never watch foreign dubbed serials for any purposes. Moreover, the outcome of the investigation exposed that $43,3 \%$ of the respondents regard foreign dubbed serials as useful and informative, $45,5 \%$ of the interviewees consider foreign dubbed serials harmful reasoning that they spread foreign cultures, change the minds of youths and teach family violence. Therefore, they suggest that the foreign dubbed serials broadcast must be banned. $11,1 \%$ of the participants' state that foreign dubbed serials have both positive and negative effects and it is the watcher how he or she follows them. The result of the research is indicative that $90 \%$ of the interviewees believe that watching foreign dubbed serials have harmful and destructive effects like kidnapping, divorce, imitating strange culture, living in pleasure, drinking wine, learning illegal love affairs, changing the minds of youths and misleading human, and $10 \%$ of the respondents think that watching of foreign dubbed serials have both positive and negative consequences. Besides, the finding of the study illustrated that $46,6 \%$ of the interviewees believe that domestic televisions' networks broadcast foreign dubbed serials to earn money from foreign countries, $30 \%$ of the participants think that domestic televisions' networks broadcast foreign dubbed serials to spread foreign culture, change the peoples' minds and mislead them, $13,3 \%$ of the interviewees deem that domestic televisions' networks broadcast foreign dubbed serials because people are very eager to watch them, and $10 \%$ of the respondents believe that domestic televisions' networks broadcast foreign dubbed serials because Afghanistan does not have domestic film and serial production to broadcast for demanders. As well, the outcome of the study demonstrated that $80 \%$ of the interviewees believe that the reason that the Afghanistan government allows the broadcast of foreign dubbed serials is that it is a colonial state and has a puppet and dependent government. Therefore, it is forced to implement the commands and aims of superpower countries via any means, $11,1 \%$ of the respondents deem that foreign dubbed serials have many demanders and watchers, $8,8 \%$ of the respondents think that carelessness of Afghan citizens is one of the main reasons that the government does not prevent the broadcast of foreign dubbed serials in Afghanistan.

\section{Discussion and conclusion}

The study aimed to explore the attitude of youths on watching foreign dubbed serials in Takhar, Afghanistan. The total outcome of the investigation reveals that nearly $96 \%$ of Afghan youths included in the study watch foreign dubbed serials. $54 \%$ of the respondents that form the majority, usually watch Turkish and Indian serials. $77 \%$ of the participants that make the maximum, watch foreign dubbed serials 2 hours in 24 hours. $81,1 \%$ of the respondents that form the highest degree, watch foreign dubbed serials for entertainment. $45,5 \%$ of the respondents consider foreign dubbed serials harmful, and $43,3 \%$ of the respondents that make the second degree, regard foreign dubbed serials as useful and informative. $90 \%$ of the participants that compose the majority believe that watching foreign dubbed serials have harmful and destructive effects like kidnapping, divorce, imitating stranger culture, living in pleasure, drinking wine, learning illegal love affairs, changing the minds of youths, and misleading individuals. $46,6 \%$ of the respondents believe that domestic televisions' networks broadcast foreign dubbed serials to earn money from foreign countries, and $30 \%$ of the participants that form the maximum one after another, think that domestic televisions' networks broadcast foreign dubbed serials to spread foreign culture, change the people's minds and mislead them. $80 \%$ of the participants believe that the reason that the Afghanistan government allows the broadcast of foreign dubbed serials is that it is a colonial state and has a puppet and dependent government that works for benefit of foreigners. The overall outcome of the study indicates that most Afghan youths have negative views concerning watching foreign dubbed serials although the majority just watch them for the aim of entertainment. The output of the investigation is identical with the findings of the studies carried out by Orfan, (2021); Naz and Iraqi (2017), Berkowitz (as cited in Anderson et al, 2003), and Stapleton (as cited in Morgan, 2002). Also, the finding of the research is similar to the statements of Hedayati, the clerk of Shia Scholar's Council in Injil district of Herat province (as cited in Sadai Afghan News Agency, 2016), Asifi (2012), Jafari, a teacher in Alzahra Educational Center (as cited in Sadai Afghan News Agency, 2016), Fooladi (as cited in Sadai Afghan News Agency, 2017), Saljooqi 'one of the media activists in Herat (as cited in Sadai Afghan News Agency, 2017), Qazi Zadeh 'the head of Kahndazh News Site in Herat (as cited in Sadai Afghan News Agency, 1396), Fars News (2014), Hashemi and Kew (2020); Anwari (as cited in BBC Persian News Agency,2008), Haqparast assistant professor of Shahid Rabani Education University (as cited in Sadai Afghan News Agency, 2012) and Enayatullah Baligh member of religious scholars' council and the Imam of Poli Kheshti Copyright $(\mathcal{C} 2021$ by IJSSER ISSN: 2149-5939 
Masjid ( as cited in Anwari,2008). However, the study outcome contradicted the findings of studies conducted by Qudah and Tahat (2013) and Khan and Rohn (2020).

The purpose of the study was to seek the view of youths on watching foreign dubbed serials in Takhar, Afghanistan. The overall finding of the investigation illustrated that most youths have a negative attitude concerning watching and broadcasting foreign dubbed serials although the majority of them watch the serials. The reason that the contents of foreign dubbed serials are against Islamic values and misleading, but most of them merely watch for the aim of entertainment. The study has implications for the ministry of information and culture and youths' parents. Although the foreign dubbed serials are broadcast frequently via national television networks and have more viewers, the attitude of youths as the main target and audience of dubbed serials are negative toward broadcasting and watching them. Thus, the ministry of information and culture as the first-rate responsible should force the national television networks to substitute useful and enabler programs instead of foreign dubbed serials which are destructive for Muslim's watchers. In addition, the ministry of information and culture in coordination with private sectors in the relevant scope should attempt to pave the way for investing and enriching national serials and film productions to become a proper alternative for strange dubbed serials and films. On the other hand, parents in charge of their families besides advising their children not to watch foreign dubbed serials should make them engaged in other informative tasks to not find an opportunity for watching the serials.

\subsection{Theoretical and practical implication}

Despite interesting findings, the study has numerous theoretical and practical implications. Among the theoretical implications, an investigation of the experiences and consequences of watching dubbed serials are the first step toward watching dubbed serials. The various antecedents could be hypothesized to have an either positive or negative impact on attitudes toward watching dubbed serials which using a theory of planned behaviour, can be hypothesized to stimulus their behaviour intentions, which in turn impact their ultimate binge-watching behaviour. While the practical implication can be as of the serials are mostly made based on themes of treachery, emotional triangular relations, and mafia relations. The serials worth to be criticized deeply. For showing their products more attractive, the producers of the serials use good looking, fresh and semi-naked clothes actors and actresses, modern cars, luxurious homes and villas and showing the modern and attractive scenes and pictures of Turkey. The content of Turkish serials emphasizes and publicizes the relationship of boy and girl as the symbol of modernism, freedom and usually, the married people try to have illegal and hidden relations. Therefore, the practical implications can be straying and lead the people to the wrong way.

\section{Author contribution statements}

B. Daqiq and A. Hashemi contributed equally to the design and implementation of the research, to the analysis of the results and to the writing of the manuscript.

\section{Disclosure statement}

No potential conflict of interest was reported by the authors.

\section{Ethics committee approval}

All responsibility belongs to the researchers. All parties were involved in the research of their own free will.

\section{References}

Alradimi, M. A., \& Al-Ali, F. A. (2019). Motives for watching dubbed TV shows by university students in the U.A.E. Global Media Journal, 17, (32), 171. Retrieved from https://www.globalmediajournal.com/open-access

Alsaawi, A. (2014). A critical review of a qualitative interview. European Journal of Business and Social Sciences, 3 (4), PP.149-156 retrieved from https://papers.ssrn.com/

Ann Morris, S. (1961). Family interaction is influenced by television for some time. Iowa: Jowa State University.

Anwari, R. (2008, May 14). The cultural differences of Indian serials. Retrieved August 5, 2020, from https://www.bbc.com/persian/arts/story/2008/04/080423_k-ram-hindi-serials

Asifi, H. (2012, June 6). Turkish serials affluent market and anger of religious clergies. Retrieved from https://www.darivoa.com/a/turkish-series-soap-opera/1596019.html

Blinn, M. (2008). The dubbing standard: Its history and efficiency implications for film distributors in the German film market. Berlin: Freie University Berlin. 
Fars News. (2014, February, 8). Seventy percent of Turkish women wear hijab but the serials are against morality. Retrieved from https://www.khabaronline.ir/news/358999/70

Fooladi, Y., Saljooqi, A., \& Qazi Zadeh, P. (2107, March, 13). Turkish and Indian Serials broadcast are not related to freedom of speech. Retrieved August, 12, 2020, from https://www.avapress.com/fa/report/148899

Hedayati, K.H. (2016, May 4). Attacking western Turkish serials on Afghan families. Retrieved from https://avapress.com/fa/90972/

Haqparast, L. (2012, January 4). The danger of foreign serials' broadcasting on youths' generation future. Retrieved from https://www.avapress.com/fa/news/57527

Hashemi, A., Kew, S. N. (2020). The Effects of Using Blended Learning in Teaching and Learning English : A Review of Literature. The Eurasia Proceedings of Educational \& Social Sciences (EPESS), 18(4), 173-179.

Hashemi, A., \& Kew, S. N. (2021). A critical discourse analysis of a news report on two mosques shooting in ChristchurchNew Zealand. International Journal of Social Sciences and Education Research,7(4),15-24. https://doi.org/10.24289/ijsser.838397

Iqbal, M. (2018). Effects of Turkish dramas on university students: A survey of Pakistani Universities. Journal of Mass Communication\& Journalism, 8 (5), DOI: 10.4172/2165-7912.1000394

Jafari, T. (2016, June). The contradiction of Turkish and Indian serials with Islamic culture and their effects on Afghans' families lives. Retrieved from https://www.avapress.com/fa/ Report/125149

Kenyon, B. (2002). The effects of televised violence on students. (Masters' Theses). Grand Valley State University, Grand Valley.

Khan, M., \& Rohn, U. (2020). Trans nationalization, exportation, and capitalization of Turkish television and its impact on the audience of Egypt and Pakistan. European Journal of Social Sciences, 59 (2), retrieved from http://www.europeanjournalofsocialsciences.com

Morgan, J. M. (2002). The effects of viewing television violence on school children. (Dissertations). Rowan University.

Naz, F., \& Iraqi, K.M. (2017). The Impact of foreign content on cultural and religious values of Pakistani society: A study of Turkish dubbed dramas. Journal of Mass Communication, 16.

O'Connor, H., \& Gibson, N. (2003). A Step-by-step guide to qualitative data analysis. A Journal of Aboriginal and Indigenous Community Health, 1(1), 63-90.

Orfan, S. N. (2021). Political participation of Afghan Youths on Facebook: A case study of Northeastern Afghanistan. Cogent Social Sciences, 7(1). https://doi.org/10.1080/23311886.2020.1857916

Qudah, M., \& Tahat, Z. (2013). Dubbed series and their possible effects on adolescents. International Journal of Scientific and Technology Research, 2 (2). 